\title{
Porphyrins and Polyoxometalate Scaffolds
}

\author{
Raphaël Lamare, Romain Ruppert, Corinne Boudon, Laurent Ruhlmann* and Jean Weiss*
}

This manuscript is dedicated to the memory of Prof. François Diederich, a fantastic scientist and mentor and, most of all, a wonderful friend.

\author{
Dr. R. Lamare, Dr. R. Ruppert, Prof. C. Boudon, Prof. L. Ruhlmann, Dr. J. Weiss \\ Institut de Chimie de Strasbourg \\ UMR 7177 CNRS-Université de Strasbourg \\ Address 4, rue Blaise Pascal, 67000 Strasbourg, France \\ E-mail: Iruhlmann@unistra, jweiss@unistra.fr \\ Supporting information for this article is given via a link at the end of the document
}

\begin{abstract}
Polyoxometalates (POMs) can act as unique reservoirs for multiple electron transfers. As POMs display only weak absorption in the visible spectrum, they can be associated to chromophores such as porphyrins and porphyrins antennae. In this review, the research dedicated to the combination of porphyrins and polyoxometalates is put in context and the state of the art identifying the challenges addressed in the optimization of hybrid materials for applications is detailed.
\end{abstract}

\section{Context}

Demographic growth, especially in developing countries, as well as the rise of the living standards, are the most obvious reasons for the actual increase of energy consumption. ${ }^{1,2}$ Nowadays, the planetary energy consumption uses fossil fuels for $80 \%$, nuclear fuels for $5 \%$ and renewable energy for $14 \%,{ }^{3}$ which generates environmental issues at the local, national and international scale. Indeed, energy production and consumption are responsible for $80 \%$ of the carbon dioxide and two thirds of the emission of greenhouse gases. ${ }^{3}$ In this regard, diversifying energy sources worldwide is a necessary requirement and the most sustainable option is to increase the contribution of renewable energy. Among all sources, the total amount of solar energy reaching Earth largely exceeds the needs of the living population and providing clean and sustainable electricity to the world will have ecologic and economic consequences on top of solving the global energetic crisis. Whereas in the past, solar cells were mainly used in small electronic devices, nowadays the solar solution is one that is most seriously foreseen. In this context, new materials that utilize the principles of photo conversion and catalysis (fuel-cell storage) known for decades, based upon optical and physical phenomena, are needed. For this reason, great efforts have been devoted both at the European and worldwide levels to develop alternatives to Si based devices. Even if the Si based modules still dominate in terms of cost/performances (both for market and research), new non Si-based materials and technologies are considered and expected to grow in the future. ${ }^{4}$ Among the more than 20 different types of photovoltaic cells that have been reported, ${ }^{5}$ aside from the dominating single crystalline or amorphous silicon derived cells, organic, dye sensitized ${ }^{6,7}$ and perovskite cells ${ }^{8}$ are the current objects of interest but the global challenge of the field is the balance of production costs vs performances and lifetime. In the search for new molecular materials for photoconversion, polyoxometalates have been

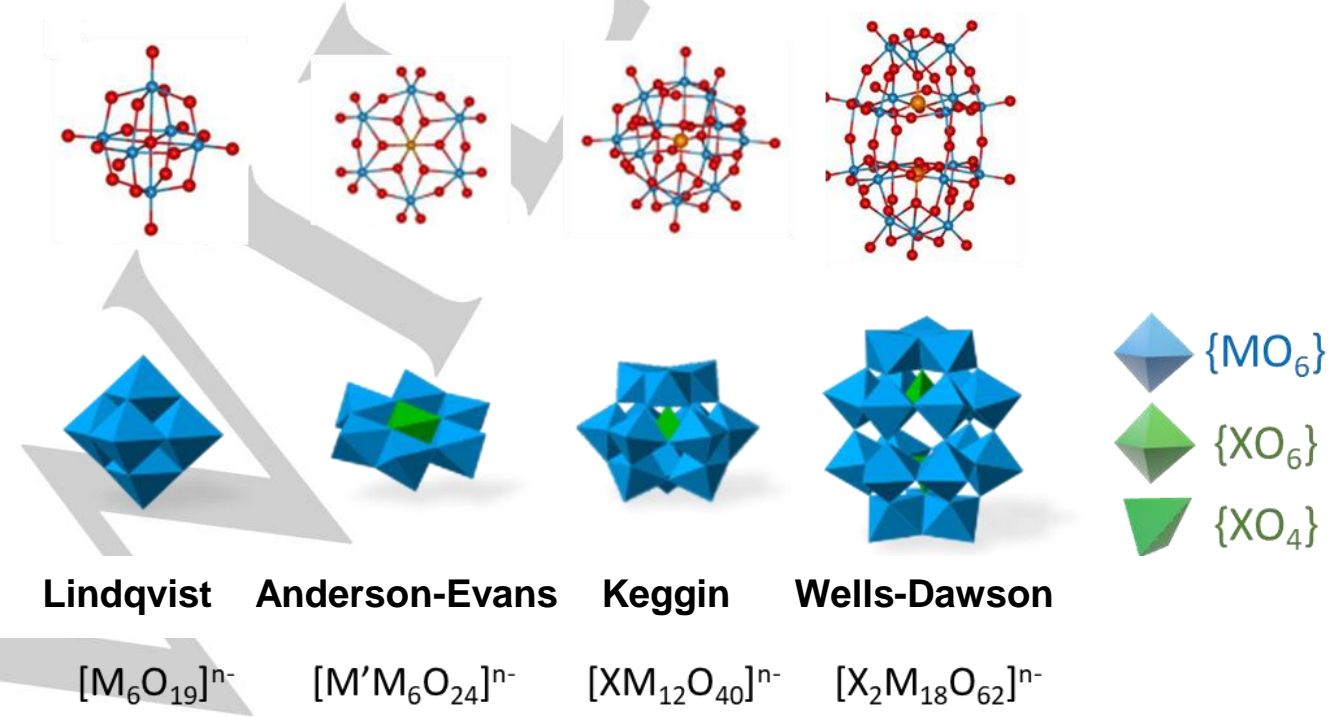

Figure 1. General formula of polyoxometalates and their various shapes. 
considered. Polyoxometalates (POMs) are anionic structures obtained by acidic condensation ${ }^{9}$ of metal oxides $\mathrm{MO}_{4}{ }^{\mathrm{n}-}$ and consist of metal oxides connected by $\mu$-oxo bridges. In general, the metal ions are Mo, $\mathrm{W}$ or $\mathrm{V}$ in their highest oxidation state, thus respectively $(+\mathrm{VI}),(+\mathrm{VI})$ and $(+\mathrm{V})$ and two types of oxygen atoms, terminal and bridging, are present. There is a large structural variety of polyoxometalates, differing by their shapes, their size and their global charge. The most common types of POMs are schematically represented by the generic structures in Figure 1 and the center of the structure can be occupied by a heteroatom such as phosphorus or silicon ( $\mathrm{X}$ in green) for example. ${ }^{10} \mathrm{POMs}$ offer a large variety of charged states and their solubility can be controlled by the nature of the counter cations. As a result, POMs have found applications in various fields such as catalysis, ${ }^{11,12,13,14}$ energy, ${ }^{15,16}$ materials ${ }^{17}$ or therapy. ${ }^{18}$ POMs have been mostly used as photocatalysts for the formation of $\mathrm{H}_{2}{ }^{19,20,21}$ or the reduction of $\mathrm{CO}_{2}^{22,23}$ due to their ability to undergo multiple (up to 6 ) and successive electron transfers. Unfortunately, their efficiency suffers from a quasi-exclusive absorption of energy in the UV region of the spectrum.

In order to enhance the energy collection, POMs can be associated to chromophores absorbing in the visible region of the solar spectrum. Porphyrin analogues such as chlorophylls and bacteriochlorophylls, the pigments of life, are involved in natural light harvesting antennae such as LH1 and LH2. ${ }^{24,25,26,27}$ Typical absorption bands of synthetic porphyrins are extremely intense in the $400-450 \mathrm{~nm}$ region of the spectrum $(\varepsilon=300000)$ and very intense in the $500-800 \mathrm{~nm}(\varepsilon=30000) .{ }^{28}$ Thus, these tetrapyrrolic macrocycles are good candidates for the sensitization of POMs.

Raphaël Lamare received his PhD in 2020 under the co-supervision of Prof. Laurent Ruhlmann and Dr. Jean Weiss after obtaining a Master degree in Chemistry and Supramolecular Chemistry from the University of Strasbourg and a research internship in synthetic Organic Chemistry. He is currently post-doctoral fellow of the Institut des Sciences Chimiques de Rennes 1.

Romain Ruppert completed his PhD in 1985 with J. P. Sauvage at the Universite Louis Pasteur (ULP). He then worked as Alexander von Humboldt fellow with E. Steckhan in Bonn and held a second post-doctoral position in the group of W. Armstrong at Berkeley. CNRS researcher since 1988, he worked successively with F. Petit, M. W. Hosseini and $\mathrm{H}$. J. Callot before joining Jean Weiss' group in 2007.
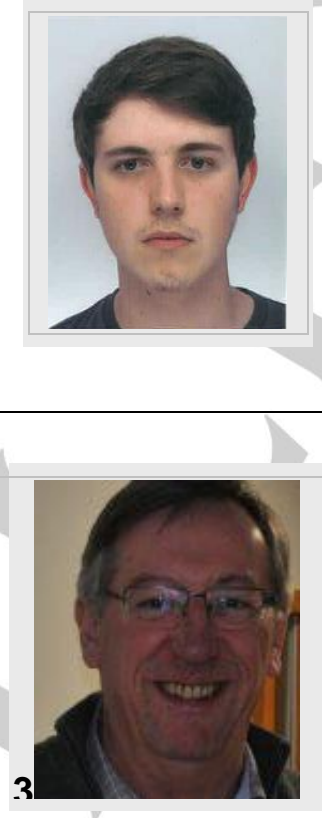

joint publications) and she is now Emeritus Professor at the University of Strasbourg since 2019.
Laurent Ruhlmann completed his $\mathrm{PhD}$ at the University of Strasbourg in 1997. After a post-doctoral position at the Freie Universität Berlin in Germany in 1998 he became associate professor at the University Paris-Sud 11. He is now full professor in chemistry since 2011 at the University of Strasbourg where he is the team leader of the Laboratory of Electrochemistry and of Chemical-Physic of the Solid State. He is expert in electrochemistry and develops hybrid materials based on (iso)porphyrin and polyoxometalate for photo (electro)catalyzed applications.

Jean Weiss received his PhD in 1986 with J.P. Sauvage (ULP). After two post-doctoral positions with D. J. Cram at UCLA and H. A. Staab at the MPI in Heidelberg as an Alexander von Humboldt fellow, he joined the group of M. Gross at the CNRS in Strasbourg. Since 2007, the group's research topics include porphyrinoïds (extended porphyrins, corroles, chlorins, phlorins), hemoprotein models, redox molecular switches, self-assembly, and molecular electronics.

\section{Scope of the review}

Whereas single porphyrin-POM hybrids are of interest to study the photochemical properties of dyads, the major purpose of POM-porphyrin combinations is to associate several porphyrins with one POM to take advantage of an antennae effect. In general, covalent methods leading to single porphyrin-POM hybrids are also suitable for associating more than one porphyrin to a POM but several methods leading to multiple-porphyrin-POM scaffolds have been designed specifically. In the following sections, scaffolds comprising porphyrins and POMs will be presented. These examples will be classified by the mode of attachment connecting the POMs and the porphyrins. The scaffolds described will be discussed in terms of properties and, when possible, the structure/properties relationship will be established. Possible approaches for the preparation of structurally controlled POM-porphyrin scaffolds will be proposed.

\section{POM-porphyrin hybrids built from coordination}

Corinne Boudon received her $\mathrm{PhD}$ in physical chemistry in 1987 from the Université Louis Pasteur working on the electrochemistry of cryptates. She has played a pivotal role in the long time collaboration between the Laboratoire d'Electrochimie et de Chimie Physique du Corps Solide and Prof. Diederich (> 100

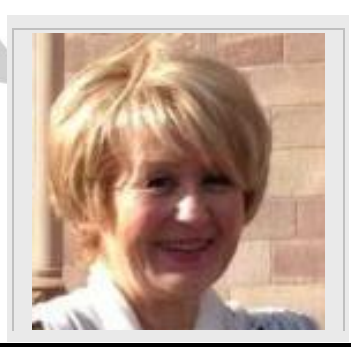




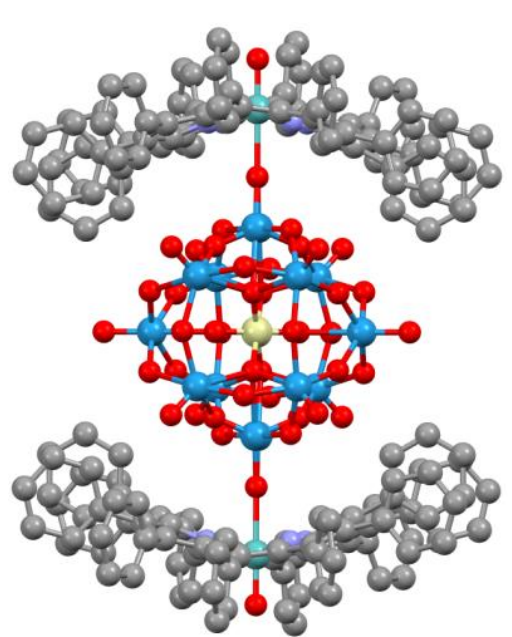

Figure 4. A Keggin POM coordinated to two distorted MoPorphyrins. Si: yellow, W: blue, O: red, Mo: aqua blue, C: grey, N: dark blue (generated from CCDC-622714
In the case of polyoxometalates and porphyrins, two strategies based on coordination have been pursued. The first consists in the axial coordination of a POM on the metal core of a metalloporphyrin. An example has been reported in which a sandwich comprising two molybdenum porphyrins

derivatives wrapped around a Keggin type POM was obtained. The two porphyrins are highly distorted dodecaphenyl-porphyrins which adopt a saddle-ruffled shape in the presence of the matching shape of a Keggin type POM (Figure 2). ${ }^{29}$ The concave shape thus favors " $\mathrm{C}-\mathrm{H} \cdots \mathrm{O}$ " interactions between the protons of some phenyl substituents on the porphyrin periphery and the oxygen atoms of the POM which complement the strong biding interaction of opposite terminal oxygen of the POM with the Mo located in the porphyrin core. The synthetic methodology has been extended to $P$ containing Keggin POMs and the Figure 3. A lacunary POM in which a terminal complexes have MO has been replaced by [Ru'l'(DMSO)]. displayed very generated with Mercury ${ }^{\mathrm{TM}}$ from $\mathrm{CCDC}$ interesting features in their crystalline packing, forming layers of tubular shaped alignments. The individual sandwich motif is maintained in solution and withstand multiple electron transfer. ${ }^{30} \mathrm{POMs}$ can be chemically modified via controlled degradation in alkali medium, removing one or more $\mathrm{M}=\mathrm{O}$ and leaving lacunary spaces surrounded by highly nucleophilic oxygen atoms. These lacunary POMs (Figure 3) can be used as ligands for metals and this has led to the development of oxidation catalysts. ${ }^{31}$ Utilizing the sandwich approach, lacunary POMs containing ruthenium as
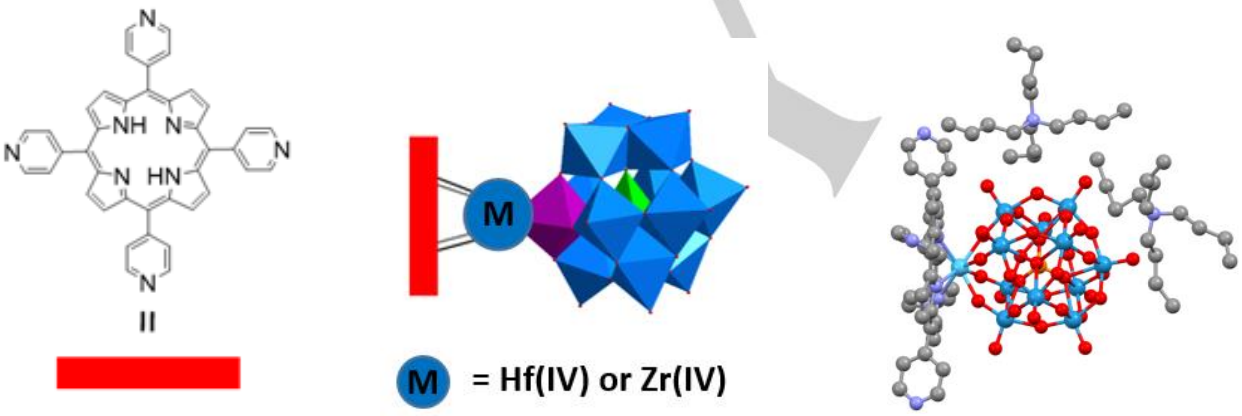

Figure 2. Schematic structure of POM-porphyrin scaffolds linked by $\mathrm{Hf}$ or $\mathrm{Zr}$ coordination and X-ray structure of the $\mathrm{Hf}^{\mathrm{IV}}$ derivative generated with Mercury ${ }^{\mathrm{TM}}$ from the CCDC file 717412 . Solvents removed for clarity.
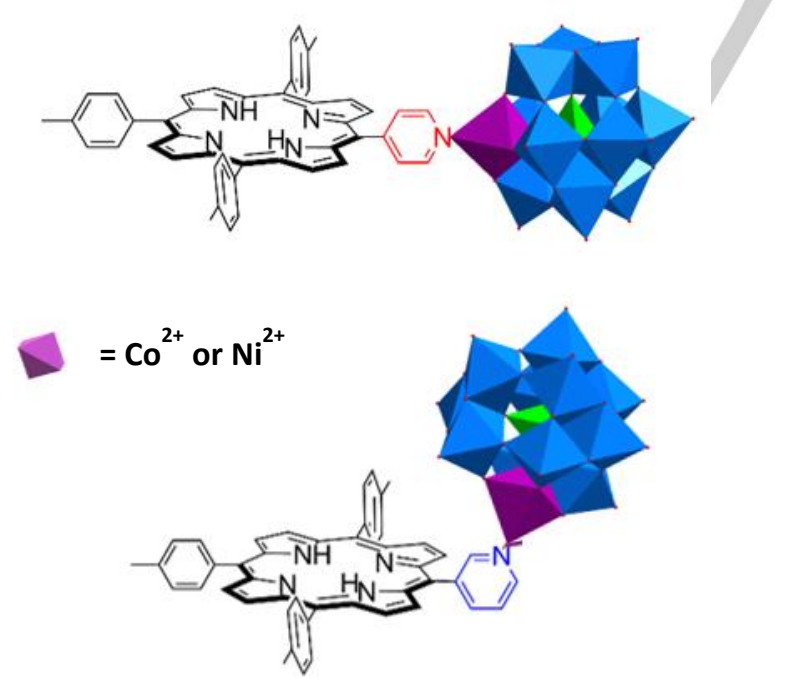

Figure 5. Schematic proposed structure of $\mathrm{H}_{2} \mathrm{~T}_{3} \mathrm{P}-4-\mathrm{Py}$ or $\mathrm{H}_{2} \mathrm{~T}_{3} \mathrm{P}-3$ Py and $\mathrm{MSiW}_{11}\left(\mathrm{M}=\mathrm{Co}^{\prime \prime}\right.$ or $\left.\mathrm{Ni}^{\mathrm{II}}\right)$. catalyst have been inserted between concave porphyrins and engaged in the oxidation of substrates such as benzyl alcohol into aldehydes. Interestingly, individual components of the sandwich have no effect on the substrates whereas the sandwich combination of the ruthenated POM and the Mo distorted porphyrins is efficient. The effect has been assigned to the significant anodic shift of the $\mathrm{Ru}^{\mathrm{IV} / \mathrm{III}}$ and $\mathrm{Ru}^{\mathrm{V} / \mathrm{IV}}$ potentials when bound to the porphyrins. ${ }^{32}$

The binding properties of lacunary POMs has also been used to form mixed species in which a metal ion is coordinated by both a porphyrin and a lacunary POM (Figure 4). ${ }^{33}$ These complexes, isolated in good yields, have been used as models for the interactions of $\mathrm{Hf}^{\mathrm{IV}}$ and $\mathrm{Zr}^{\mathrm{IV}}$ porphyrin derivatives with surfaces such as ITO and the application of porphyrins in the sensitization of ITO based photovoltaic devices.

The second approach involves the presence of coordinating heteroatoms in the porphyrin structure, which can bind to a metal complex derived from a lacunary POM. The preparation of such metal complexes has been largely exploited in the Lindqvist series and the imido-POMs are the most commonly prepared by treatment of the $\left[\mathrm{Mo}_{6} \mathrm{O}_{19}\right]^{2-}$ cluster with iminophosphoranes ${ }^{34}$ or 

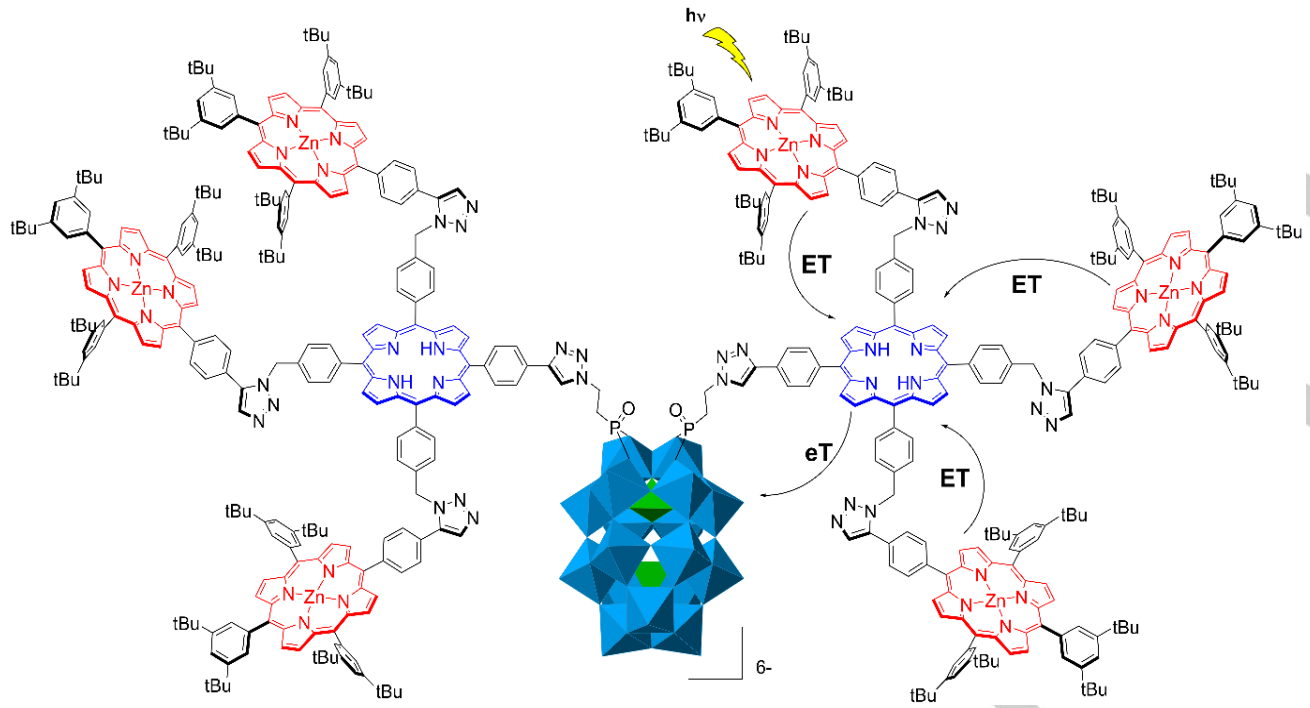

Figure 8. Photosynthetic mimic comprising a porphyrin antennae and a Wells-Dawson POM for charge storage.

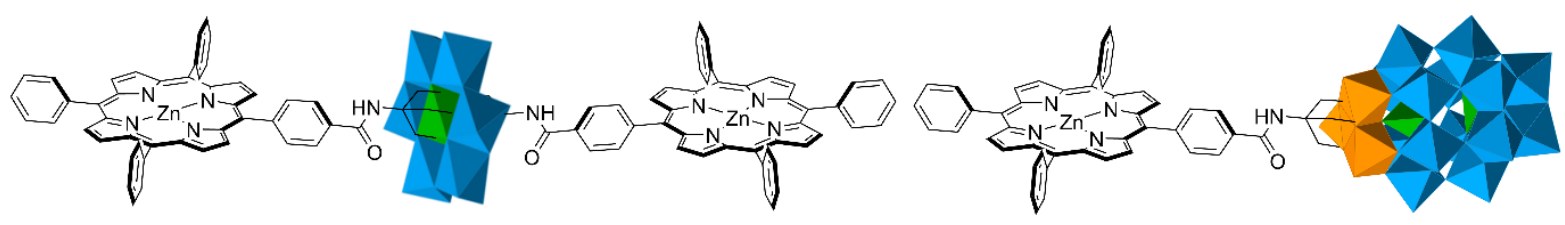

Figure 7. Tris-alkoxy substitution leading to (left): Anderson-Evans POM based bis-porphyrin hybrid and (righ): Wells-Dawson POM porphyrin hybrid.

isocyanides. ${ }^{35}$ One of the first examples of coordination complex on a POM in which one terminal $\mathrm{Mo}=\mathrm{O}$ had been replaced by a transition metal was demonstrated by ${ }^{1} \mathrm{H}$ NMR, ${ }^{36}$ providing evidence for interaction between pyridine and imidazole with $\alpha$ $\left[\mathrm{CoSiW}_{11} \mathrm{O}_{39}\right]^{6-}$ or $\alpha-\left[\mathrm{NiSiW}_{11} \mathrm{O}_{39}\right]^{6-}$. More recently, several examples of organic-inorganic hybrids using this approach have been reported. In particular, pyridine appended porphyrins have been combined with $\mathrm{Co}$ " or $\mathrm{Ni}^{\mathrm{II}}$ inserted in lacunary Keggin type POMs (Figure 5). ${ }^{37}$ For the complexes in Figure 5, association as high as $10^{6} \mathrm{M}$ have been measured by monitoring the extinction of luminescence for the porphyrin in the presence of the POM. More recently, several nitrogen ligands such as pyridine, 4,4'bipyridine and meso-tetrakis-(4-pyridyl)-porphyrin (Figure 4) have been used in the competitive formation of self-assembled face-toface lacunary Keggin type phosphomolybdates and face-to-face bis porphyrins. ${ }^{38}$

Of course, the formation of coordination hybrids always depends on the strength of the coordination bond and the use of covalent bond formation has also attracted the attention of synthetic chemists.

\section{Covalent POM-porphyrin hybrids}

The replacement of terminal hydroxy ligands by alkoxy substituents on POM provides a simple access to attaching molecular sub-units to the inorganic structure. Similarly bridging oxygen atoms can also be turned into bridging oxygen atoms from alkoxy groups. Although at the time the connection has been classified as coordination, the first replacement of a hydroxo on a polyoxovanadate has been reported as early as 1992. In the resulting structure, the stabilization of the hexavanadate core by the alkoxy ligands has been established and assigned to the reduction of the total (negative) charge of the cluster. ${ }^{39}$ Similar effects have been observed in a Keggin type phosphotungstate in



Figure 6. Linear porphyrin dimer connected by a Lindqvist type POM (generated with Mercury ${ }^{\mathrm{TM}}$ from CCDC file 961099). 
which a bridging oxo has been alkylated. Interestingly the latter method leaves the structure unaltered. 40 Most of the functionalization methods employed for the preparation of the covalent POM-porphyrin hybrids presented hereafter have been covered in several reviews and will not be detailed. ${ }^{41}$ In 2009, two porphyrins have been introduced on a WellsDawson POM using linkers which disrupt any electronic coupling between the two porphyrins. ${ }^{42}$ The synthesis utilized a generic functionalization of a POM precursor reported at the turn of the century which opened the way to many chromophore decorated POMs, ${ }^{43}$ using classical clickchemistry conditions. ${ }^{44} \mathrm{~A}$ few years later, the same approach has been employed to attach an antennae network of porphyrins to a WellsDawson POM (Figure 6). ${ }^{45}$ Remarkably, an energy cascade was introduced in the covalent scaffold in which zinc porphyrins collected energy to be transferred (ET) to a free base (metal free) porphyrin for a final electron transfer (eT) to the POM.

Several other covalent POM-porphyrin scaffolds have been reported using a tris-alkoxy substitution of three hydroxyl group that can be applied to all types of POMs. ${ }^{46}$ Among these, the hybrids described in (Figure 6) combined Anderson-Evans POMs $\alpha-\left[\mathrm{MnMo}_{6} \mathrm{O}_{24}\right]^{4}$ and Wells-Dawson $\left[\mathrm{P}_{2} \mathrm{~V}_{3} \mathrm{~W}_{15} \mathrm{O}_{62}\right]^{9-}$ types were used to observe photo-induced electron transfers from the porphyrins to the POM in the Wells-Dawson case only. ${ }^{47}$ In this derivative, photophysical studies yielded a transfer rate of $k^{\mathrm{s1}}{ }_{\mathrm{et}}=$ $1,6 \times 10^{10} \mathrm{~s}^{-1}$ which is consistent with literature values for dyads using Zn porphyrins. ${ }^{48,49,50,51}$

The Wells-Dawson hybrid depicted in Figure 7. has been deposited on ITO plates and the instantaneous generation of photocurrent under irradiation in the visible region has been observed using $\mathrm{I}_{3}-\mathrm{I}^{-}$as redox relay. ${ }^{52}$

Recently, the synthesis and structure of a Lindqvist type hexavanadate covalently linked to two zinc porphyrins has been reported. For the first time, the hybrid structure was characterized by X-ray diffraction (Figure 8. Linear porphyrin dimer connected by a Lindqvist type POM (generated with Mercury ${ }^{\mathrm{TM}}$ from CCDC file 961099). Figure 8). The scaffold has been utilized for the photocatalytic degradation of pollutants in aqueous media. ${ }^{53}$

Similar structures bearing one, two (cis and trans) or three WellsDawson type polytungstates $\left[\mathrm{V}_{3} \mathrm{P}_{2} \mathrm{~W}_{15} \mathrm{O}_{62}\right]^{9-}$ have been reported. When non-centrosymmetric, the porphyrin/POM hybrids were used in third order non-linear optic applications ${ }^{54,55}$ but more generally, this class of hybrids is well suited for catalysis in general and more particularly acetylation reactions ${ }^{56}$ or alkene epoxidation with $\mathrm{NaIO}_{4}{ }^{57}$ when manganese or tin tetrakis $(p$ aminophenylporphyrin) linked to four Lindqvist hexamolybdate are used. Very recently, two new looped covalently bonded Anderson-Evans-type polyoxometalate-porphyrin hybrids composed of two Anderson-Evans-type POM moieties and two porphyrin moieties were synthesized. ${ }^{58}$

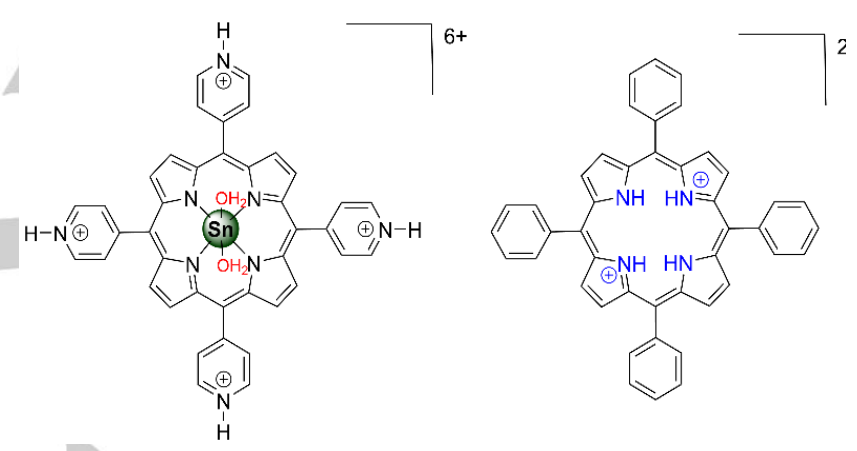

Figure 10. Protonated porphyrins which were combined with Keggin type POMs for hydrogen production (left) and non-linear optics (right).

The preparation of a hybrid material in which tetrakis $(p-$ aminophenylporphyrin) is covalently linked to a Lindqvist structure of polyoxometalate, is also reported. The direct coupling of the hexamolybdate polyoxoanion, $\left[\mathrm{Mo}_{6} \mathrm{O}_{19}\right]^{2-}$ and tetrakis(4aminophenyl)porphyrin, was successful using dicyclohexylcarbodiimide (DCC) as a coupling reagent. ${ }^{56,57}$

\section{Electrostatic Hybrids}

Due to their polyanionic nature, POMs are able to interact with positively charged molecular components. Cationic porphyrins that have been mostly developed to enhance their solubility in aqueous media are thus well suited to form assemblies with POMs based on the development of electrostatic interactions. In 2000, the first supramolecular complexes resulting from the combination of species depicted in Figure 9 Figure 1have been reported in the literature. ${ }^{59}$

Many cationic porphyrins obtained by simple alkylation of porphyrins bearing pyridine substituents have been reported but similar species obtained by protonation can also be combined with Keggin type POMs. The two species represented in Figure 10 illustrate this easy access to hybrid scaffolds with Keggin POMs which can be used for photocatalytic $\mathrm{H}_{2}$ production ${ }^{60}$ or in 
non-linear optics. ${ }^{61}$ The hybrids have shown electrocatalytic activity for the oxygen reduction reaction (ORR). Other catalytic studies performed with similar hybrids such as the oxidation of (cis)-enes, geraniol and terpenes have involved POM-porphyrin hybrids assembled by electrostatic interactions. ${ }^{62}$

Ideally, in order to maximize the interactions, neutrality should be reached. The combination represented in Figure 11 Erreur ! Source du renvoi introuvable.matches 16 negative charges on a Wells-Dawson type POM sandwich with four tetracationic porphyrins to form a
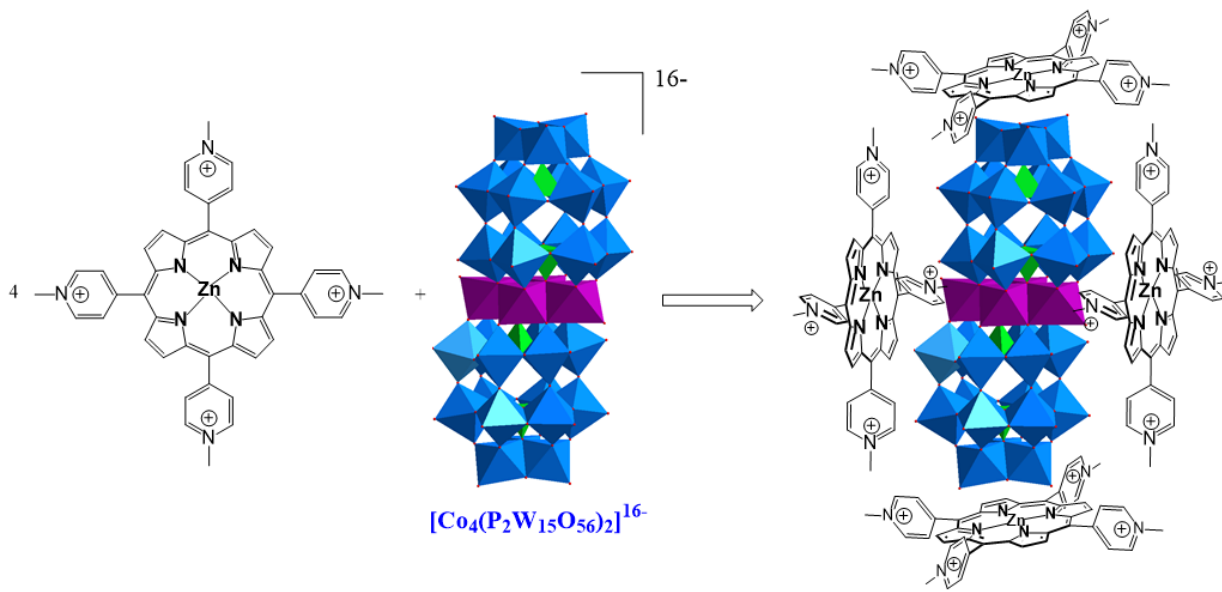

Figure 11. Idealized structure of a neutral electrostatic assembly formed meso-tetrakis(N-methyl-4-pyridium)-Zn porphyrin and a Keggin POM sandwich.

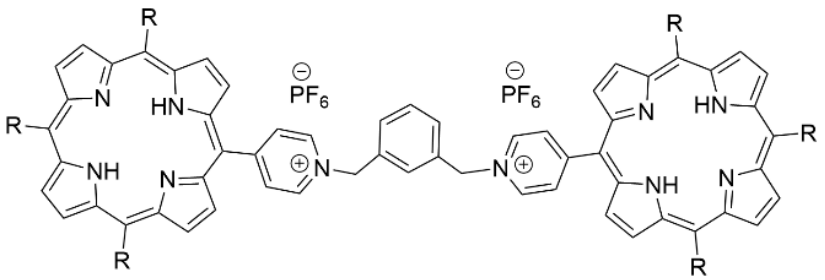

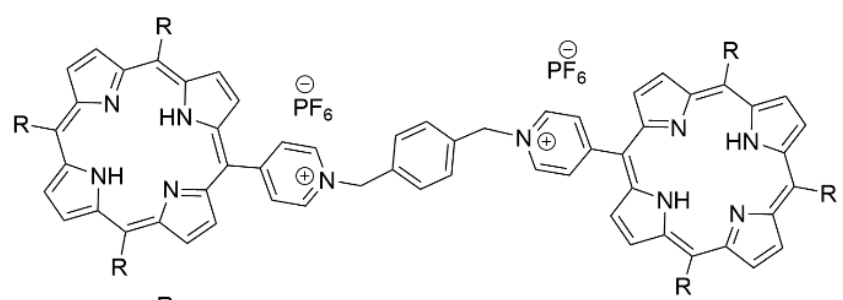

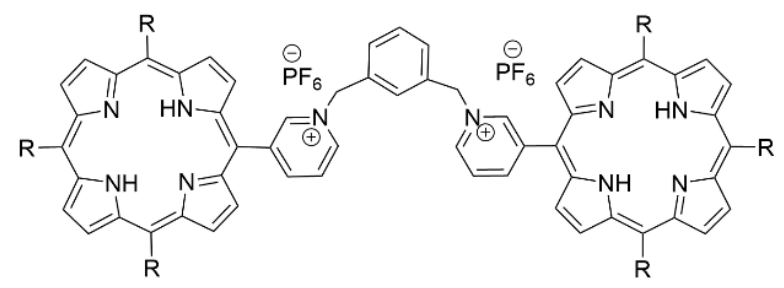

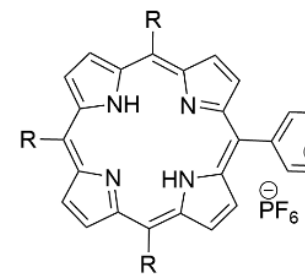<smiles></smiles>

$\mathrm{R}=p-\mathrm{CH}_{3}\left(\mathrm{C}_{6} \mathrm{H}_{4}\right)-$

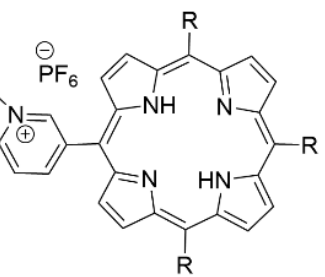

Figure 12. Series of dicationic tweezers shaped porphyrin dimers obtained by stepwise quaternization.

neutral assembly for which an ideal structure is proposed. ${ }^{63}$ Similar systems were obtained with other tetracationic species derived from octaethylporphyrin and the activity of these scaffolds has been demonstrated by the photoreduction of $\mathrm{Ag}^{+}$in the case of Keggin type POMs. ${ }^{64}$

However, all the structures represented here are idealized and a rational analysis of the performances in the light of structural data remains difficult. Tweezers shaped porphyrin dimers having positive charges in precise locations have been prepared and are represented in Figure 12.65

Preliminary studies show that depending on the positioning of the charges, association constants with a Lindqvist type POM vary from $\log \mathrm{K}_{\mathrm{a}}=2.6$ to 4.2 and that the fluorescence quenching of the porphyrin results from the formation of a host guest complex and interactions in the ground state.

\section{Layer by layer Assembling}

Pioneering works have described the formation of layer-by-layer (LbL) assemblies on glassy carbon electrodes. Using polytungstates containing either $\mathrm{P}$ or $\mathrm{Si}$ as heteroatoms, the better stability of Si containing multilayered films was demonstrated ${ }^{66}$ and the resulting modified electrode were used for electroinduced hydrogen evolution reaction and two electron oxygen

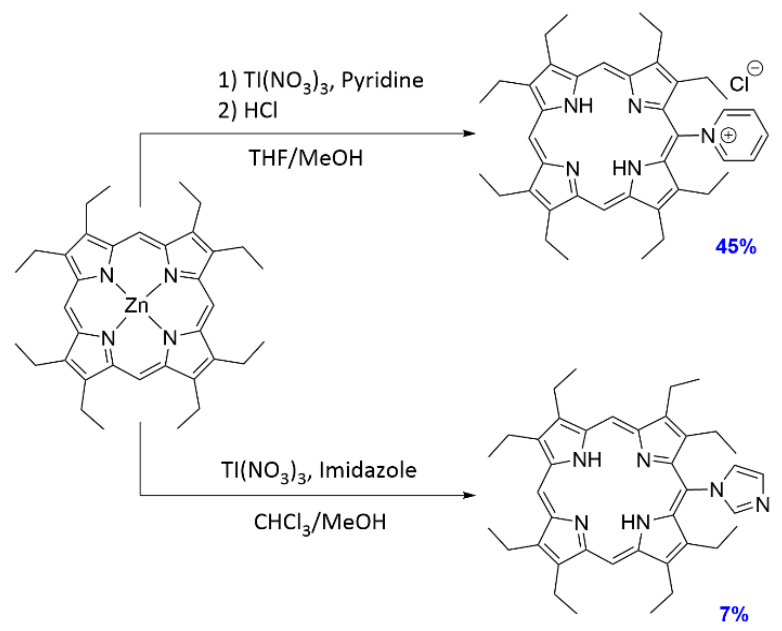

Figure 13. Two substitutions of an octaethylporphyrin radical cation. 

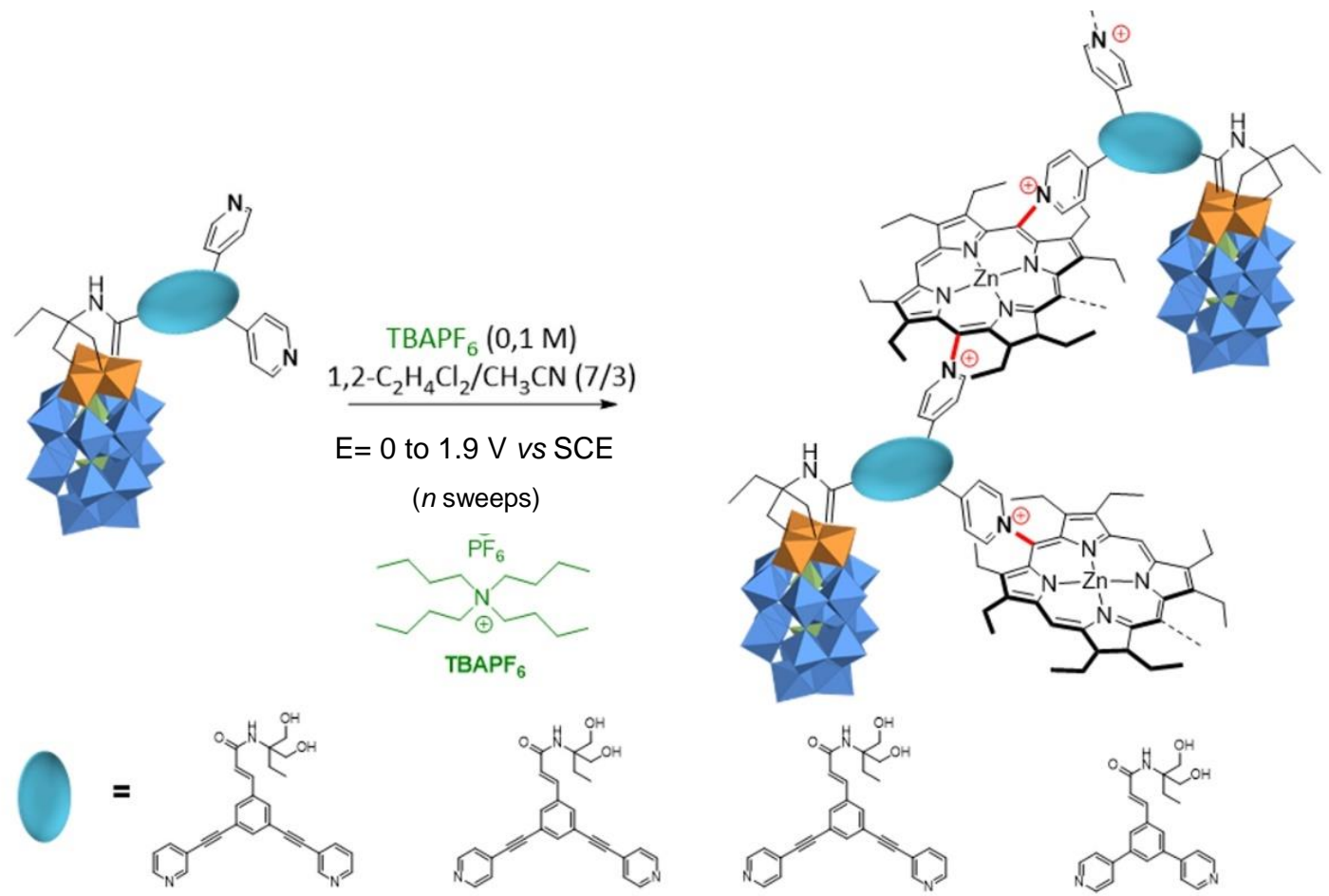

Figure 14. Porphyrin/POM copolymers with bridging bis-pyridine attached to the POM unit.

reduction reaction with cobalt porphyrins. ${ }^{67,68}$ After deposition, the stability of LbL films obtained in the case of tetrapyridinium porphyrin (free base and zinc complex) and a europium containing polyoxometalate EuPW11039K4 has been demonstrated by AFM studies. The structure of the films on glass, mica and ITO has been investigated and have shown that the thickness of the deposited layers might be different from one substrate to another. For example, the thicknesses of films on glass and ITO are approximately 3 times thinner when compared to films on mica. ${ }^{69}$ Although linear UV absorption evolution is generally used as proof of LbL deposition, models ${ }^{70}$ suggest that AFM experiments are the ultimate proof of the homogeneous deposition of a hybrid on a substrate. The pronounced chromophoric activity of the porphyrin constituent in the LbL hybrid materials has consequently involved the use of transparent ITO electrodes in photovoltaic applications. Efficient photocurrent generation can be obtained by combining a Fe substituted POM $\left[\alpha_{2} \mathrm{Fe}^{\mathrm{III}} \mathrm{P}_{2} \mathrm{~W}_{17} \mathrm{O}_{61}\right]^{7-}$ and a tetracationic porphyrin $5,10,15,20$ tetrakis-(4-trimethylammonium)-phenyl)-porphyrin. ${ }^{71}$

A mixture of a cationic cobalt 5,10,15,20-tetrakis(1-methyl-4pyridinio)porphyrin and an anionic metatungstate (POM) supported on graphite carbon was developed as a high performance novel cathode catalyst using a rotating ring-disk electrode for the oxygen reduction reaction (ORR) with high current density and low hydrogen peroxide production in a fuel cell. ${ }^{72}$

\section{Porphyrin metal organic frameworks (PMOFs)}

Inspired by the fast growing research on metal organic frameworks (MOFs) which give access to multidimensional porous structures, ${ }^{73,74}$ coordination based approaches of POM- porphyrin hybrid materials have been developed, leading to POM containing MOFs. These self-organized structures contain tetrakis-(4-pyridyl)-porphyrin linkers connecting ferrous or cuprous ions, forming a 3D cationic porous network. Within the pores hexamolybdates can be accommodated and fill the pore regularly to reach charge neutrality for the resulting scaffold. ${ }^{75}$ Porphyrin based MOFs are attractive due to their bio-relevance regarding light harvesting and catalytic processes. ${ }^{76}$ Among these, zirconium based porphyrin MOFs like MOF-545 ${ }^{77}$ (porphyrin tetracarboxylate) are extremely porous and provide space to accommodate large species such as $\left[\left(\mathrm{PW}_{9} \mathrm{O}_{34}\right)_{2} \mathrm{CO}_{4}\left(\mathrm{H}_{2} \mathrm{O}\right)_{2}\right]^{10-}$ for noble metal-free photocatalytic water oxidation. ${ }^{78,79}$ Porphyrins bearing carboxylate functions can also be directly associated with Keggin type POMs to form porous networks with catalytic properties such as the selective oxidation of olefins, ${ }^{80}$ the oxidation of alkylaryls with $\mathrm{Mn}$ porphyrins ${ }^{81}$ and the reduction of $\mathrm{CO}_{2} \cdot{ }^{82}$

\section{Hybrid copolymers}

As large aromatic macrocyles, porphyrins can undergo electron transfers to generate rather stable species which reactivity can be controlled. For more than four decades, it is known that the radical cation of octaethylporphyrins can react with a nucleophile to generate a cationic adduct such as that described in Figure 13Figure $13 .{ }^{83}$

Since the initial observation, electrochemical alternative methods have been developed to form the radical cations at the surface of electrodes. Similar reactivity has also been found for tetraphenyl porphyrins ${ }^{84}$ and the use of linearly bridging nucleophiles, like 4,4 '-bipyridine, has allowed to form films of polymers at the surface of electrodes. ${ }^{85,86}$ When performed in the presence of POMs, the later could be incorporated in the well-organized 
polymer films. ${ }^{87}$ To strengthen the connection between the POM species and the porphyrins in the electrogenerated porphyrinbipy-POM polymers, the bridging nucleophile can be built on the POM itself as represented in Figure 14.

The films produced using this method generate stable photocurrents under visible irradiation. The intensity of the current depends on the type of bis-pyridine spacer, the film thickness and finally of the applied potential on the ITO electrode. ${ }^{88}$

Using similar method, four hybrid polyoxometalate-porphyrin copolymer films were also obtained by the electrooxidation of zinc- $\beta$-octaethylporphyrin or free base 5,15-ditolylporphyrin in the presence of organosilyl functionalized Keggin-type POMs $\mathrm{TBA}_{3}\left[\mathrm{PW}_{11} \mathrm{Si}_{2} \mathrm{O}_{40} \mathrm{C}_{26} \mathrm{H}_{16} \mathrm{~N}_{2}\right]$ and Wells-Dawson-type POMs $\mathrm{TBA}_{6}\left[\mathrm{P}_{2} \mathrm{~W}_{17} \mathrm{Si}_{2} \mathrm{O}_{62} \mathrm{C}_{26} \mathrm{H}_{16} \mathrm{~N}_{2}\right]$ bearing two remote pyridyl groups. Their impedance properties were and their photovoltaic performances were investigated showing a correlation between impedance and photovoltaic performances, the films based on Wells-Dawson type POMs and $\mathrm{Zn}$ porphyrins giving the best results. This last system displayed one of the best photocurrent efficiency for a reported POM photosensitized hybrid $(-7,2 \mu \mathrm{A} . \mathrm{cm}$ 2). ${ }^{89}$

The highest current density value measured in an optimized film was $-7,2 \mu \mathrm{A} . \mathrm{cm}^{-2}$ which is at least four times the value observed for polymers sensitized by ruthenium complexes 90 or phthalocyanine sensitized polymers ${ }^{91,92}$ and are close to those observed in hemicyanines sensitized POMs. ${ }^{93}$ Interestingly, the performance of the polymers is best when the connection between the POM and the porphyrin is well-defined than when POMs are combined with porphyrin oligomers by electrostatic interactions.

Finally, recently, the introduction of nanoparticles (MNPs) at the surface of cationic poly-porphyrin films, obtained by electrostatic interaction between the bis-porphyrin copolymer and the Preyssler type polyoxometalate $\mathrm{P}_{5} \mathrm{~W}_{30} @ M N P s$, enhances the photocurrent (up to 2.5-3 times greater as a function of the used nanoparticle). ${ }^{94}$

\section{Conclusion}

The combination of porphyrins with POMs has greatly enlarged its field of applications over the last decades. While hybrid materials obtained at the mesoscale by oligomerization and selfassembly at the surface of electrodes, their intimate structure is usually more idealized than precisely determined. In general, the performances of molecular species described in this mini-review are better than those of bulk POM-porphyrins combinations. Thus the performances of the hybrid materials could benefit from detailed structural information obtained from models assemblies utilizing the same interactions to associate POMs and porphyrins. For example, systematic studies of the charge localization on the porphyrins in electrostatic assemblies may help to obtain more efficient hybrid materials through a rational analysis of their structure-properties relationships and such investigations require significant efforts in supramolecular chemistry and porphyrin synthesis, two emblematic fields which have been explored indepth by our mentor and friend François Diederich during his brilliant career.

\section{Acknowledgements}

All authors are thankful to the University and the CNRS for constantly supporting their work. RL acknowledge the Fondation Recherche en Chimie ic-FRC of the University of Strasbourg and the Region Grand-Est for a PhD. Fellowship.

Keywords: Porphyrins • Polyoxometalates • Self-Organization • Electrochemistry $\cdot$ Photochemistry

[1] K. Kaygusuz, Renew. Sustain. Energy Rev., 2012, 16, 1116 1126.

[2] B. Mignacca, G. Locatelli, Renew. Sustain. Energy Rev., 2020, 118, 109519.

[3] "World Energy Outlook 2015 - Analysis" can be found under https://www.iea.org/reports/world-energyoutlook-2015.

[4] Source: European Photovoltaic Industry Association (Solar Power Europe since 2015). http://www.epia.org/fileadmin/user_upload/Publicatio ns/GMO_2013_-_Final_PDF.pdf.

[5] T. M. Bruton, Sol. Energy Mater. Sol. Cells, 2002, 72, 3-10.

[6] G. Conibeer, Mater. Today, 2007, 10, 42-50.

[7] G. Conibeer, M. Green, R. Corkish, Y. Cho, E.-C. Cho, C.W. Jiang, T. Fangsuwannarak, E. Pink, Y. Huang, T. Puzzer, T. Trupke, B. Richards, A. Shalav, K. Lin, Thin Solid Films, 2006, 511, 654-662.

[8] Kojima, K. Teshima, Y. Shirai, T. Miyasaka, J. Am. Chem. Soc., 2009, 131, 6050-6051.

[9] G. Hervé, A. Tézé, General Principles of the Synthesis of Polyoxometalates in Aqueous Solution, 2003.

[10] W. G. Klemperer, in Inorg. Synth., John Wiley \& Sons, Ltd, 2007, 71-85.

[11] S.-S. Wang, G.-Y. Yang, Chem. Rev., 2015, 115, 4893-4962.

[12] M. Sadakane, E. Steckhan, Chem. Rev., 1998, 98, 219-238.

[13] M. Zhang, Y. Zhai, S. Ru, D. Zang, S. Han, H. Yu, Y. Wei, Chem. Commun., 2018, 54, 10164-10167.

[14] D. Ravelli, S. Protti, M. Fagnoni, Acc. Chem. Res., 2016, 49, 2232-2242.

[15] Y. Ji, L. Huang, J. Hu, C. Streb, Y.-F. Song, Energy Environ. Sci., 2015, 8, 776-789.

[16] Y.-J. Wang, W.-L. Chen, L. Chen, X.-T. Zheng, S.-S. Xu, E.B. Wang, Inorg. Chem. Front. 2017, 4, 559-565.

[17] C. Busche, L. Vilà-Nadal, J. Yan, H. N. Miras, D.-L. Long, V. P. Georgiev, A. Asenov, R. H. Pedersen, N. Gadegaard, M. M. Mirza, D. J. Paul, J. M. Poblet, L. Cronin, Nature, 2014 515, 545-549.

[18] H.-K. Yang, Y.-X. Cheng, M.-M. Su, Y. Xiao, M.-B. Hu, W. Wang, Q. Wang, Bioorg. Med. Chem. Lett., 2013, 23, 1462-1466.

[19] H. Lv, Y. V. Geletii, C. Zhao, J. W. Vickers, G. Zhu, Z. Luo, J. Song, T. Lian, D. G. Musaev, C. L. Hill, Chem. Soc. Rev., 2012, 41, 7572-7589.

[20] X.-J. Kong, Z. Lin, Z.-M. Zhang, T. Zhang, W. Lin, Angew. Chem. Int. Ed Engl., 2016, 55, 6411-6416.

[21] H. Lv, W. Guo, K. Wu, Z. Chen, J. Bacsa, D. G. Musaev, Y. V. Geletii, S. M. Lauinger, T. Lian, C. L. Hill, J. Am. Chem. Soc., 2014, 136, 14015-14018.

[22] J. Ettedgui, Y. Diskin-Posner, L. Weiner, R. Neumann, J. Am. Chem. Soc., 2011, 133, 188-190.

[23] E. Haviv, L. J. W. Shimon, R. Neumann, Chem. Eur. J., 2017, 23, 92-95. 
[24] W. Kühlbrandt, D. N. Wang and Y. Fujiyoshi, Nature, 1994 367, 614.

[25] G. McDermott, S. M. Prince, A. A. Freer, A. M. Hawthornthwaite-Lawless, M. Z. Papiz, R. J. Cogdell, N. W. Isaacs, Nature, 1995, 374, 517.

[26] R. J. Cogdell, N. W Isaacs, A. A. Freer, T. D. Howard, A. T. Gardiner, S. M. Prince, M. Z. Papiz, FEBS Lett., 2003, 555, 35.

[27] M. Z. Papiz, S. M. Prince, T. Howard, R. J. Cogdell, N. W. Isaacs, J. Mol. Biol., 2003, 326, 1523.

[28] For an introduction to porphyrins from the point of view of synthetic chemists see: J. A. Wytko, R. Ruppert, C. Jeandon, J. Weiss Chem. Commun., 2018,54, 1550-1558.

[29] Yokoyama, T. Kojima, K. Ohkubo, S. Fukuzumi, Chem. Commun., 2007, 3997-3999.

[30] Yokoyama, T. Kojima, K. Ohkubo, S. Fukuzumi, Inorg. Chem., 2010, 49, 11190-11198.

[31] R. Neumann, C. Abu-Gnim, J. Am. Chem. Soc., 1990, 112, 6025-6031; b) M. Sadakane, D. Tsukuma, M. H. Dickman, B. Bassil, U. Kortz, M. Hagashijima, W. Ueda, Dalton Trans., 2006, 4271- 4276.

[32] Yokoyama, K. Ohkubo, T. Ishizuka, T. Kojima, S. Fukuzumi, Dalton Trans., 2012, 41, 10006-10013.

[33] Falber, B. P. Burton-Pye, I. Radivojevic, L. Todaro, R. Saleh, L. C. Francesconi, C. M. Drain, Eur. J. Inorg. Chem. 2009, 17, 2459-2466.

[34] Y. Du, A. L. Rheingold, E. A. Maatta, J. Am. Chem. Soc., 1992, 114, 345-346.

[35] J. B. Strong, R. Ostrander, A. L. Rheingold, E. A. Maatta, J. Am. Chem. Soc., 1994, 116, 3601-3602.

[36] J. Park, J. Y. Kim, H. So, J. Liu, Inorganica Chim. Acta, 2001, 319, 8-14.

[37] D. Schaming, C. Costa-Coquelard, I. Lampre, S. Sorgues, M. Erard, X. Liu, J. Liu, L. Sun, J. Canny, R. Thouvenot, L. Ruhlmann, Inorganica Chim. Acta, 2010, 363, 2185-2192.

[38] Li, N. Mizuno, K. Yamaguchi, K. Suzuki, J. Am. Chem. Soc., 2019, 141, 7687-7692.

[39] Q. Chen, D. P. Goshorn, C. P. Scholes, X. L. Tan, J. Zubieta, J. Am. Chem. Soc., 1992, 114, 4667-4681

[40] W. H. Knoth, R. L. Harlow, J. Am. Chem. Soc., 1981, 103, 4265-4266.

[41] a) Proust, R. Thouvenot, P. Gouzerh, Chem. Commun., 2008, 1837-1852; b) A. Proust, B. Matt, R. Villanneau, G. Guillemot, P. Gouzerh, G. Izzet, Chem. Soc. Rev., 2012, 41 7605-7622; c) P. Gouzerh, A. Proust, Chem. Rev., 1998, 98, 77-111.

[42] Harriman, K. J. Elliott, M. A. H. Alamiry, L. L. Pleux, M. Séverac, Y. Pellegrin, E. Blart, C. Fosse, C. Cannizzo, C. R. Mayer, F. Odobel, J. Phys. Chem. C, 2009, 113, 5834-5842.

[43] F. Odobel, M. Séverac, Y. Pellegrin, E. Blart, C. Fosse, C. Cannizzo, C. R. Mayer, K. J. Elliott, A. Harriman, Chem. Eur. J., 2009, 15, 3130-3138.

[44] V. D. Bock, H. Hiemstra, J. H. van Maarseveen, Eur. J. Org. Chem., 2006, 51-68; b) V. V. Rostovtsev, L. G. Green, V. V. Fokin, K. B. Sharpless, Angew. Chem. Int. Ed., 2002, 41, 2596-2599.

[45] K. J. Elliott, A. Harriman, L. Le Pleux, Y. Pellegrin, E. Blart, C. R. Mayer, F. Odobel, Phys. Chem. Chem. Phys. PCCP 2009, 11, 8767-8773.

[46] H. M. Asif, Y. Zhou, L. Zhang, N. Shaheen, D. Yang, J. Li, Y. Long, A. Iqbal, Y. Li, Inorg. Chem., 2017, 56, 9436-9447.
[47] Allain, D. Schaming, N. Karakostas, M. Erard, J.-P. Gisselbrecht, S. Sorgues, I. Lampre, L. Ruhlmann, B. Hasenknopf, Dalton Trans., 2013, 42, 2745-2754.

[48] M. Brun, A. Harriman, V. Heitz, J. P. Sauvage, J. Am. Chem. Soc., 1991, 113, 8657-8663.

[49] J. Rodriguez, C. Kirmaier, D. Holten, J. Am. Chem. Soc., 1989, 111, 6500-6506.

[50] J. Liu, J.-W. Huang, H. Shen, H. Wang, H.-C. Yu, L.-N. Ji, Dyes Pigm., 2008, 77, 374-379.

[51] Leray, B. Valeur, D. Paul, E. Regnier, M. Koepf, J. A. Wytko, C. Boudon, J. Weiss, Photochem Photobiol Sci., 2005, 280286.

[52] Ahmed, R. Farha, Z. Huo, C. Allain, X. Wang, H. Xu, M. Goldmann, B. Hasenknopf, L. Ruhlmann, Electrochimica Acta, 2013, 110, 726-734.

[53] Y. Zhu, Y. Huang, Q. Li, D. Zang, J. Gu, Y. Tang, Y. Wei, Inorg. Chem., 2020, 59, 2575-2583.

[54] Iqbal, H. M. Asif, Y. Zhou, L. Zhang, T. Wang, F. Khurum Shehzad, X. Ren, Inorg. Chem., 2019, 58, 8763-8774.

[55] S. ul Hassan, H. M. Asif, Y. Zhou, L. Zhang, N. Qu, J. Li, Z. Shi, J. Phys. Chem. C, 2016, 120, 27587-27599.

[56] M. Araghi, V. Mirkhani, M. Moghadam, S. Tangestaninejad, I. Mohammdpoor-Baltork, Dalton Trans., 2012, 41, 11745-11752.

[57] M. Araghi, V. Mirkhani, M. Moghadam, S. Tangestaninejada, I. Mohammdpoor-Baltorka, Dalton Trans., 2012, 41, 3087-3094.

[58] H. M. Asifa, A. Iqbal; Y. Zhou, L. Zhang, T. Wang, M. Inam, U. Farooqi, R.Sun, Dyes Pigm., 2021, 184, 108758.

[59] S.-Q. Liu, J.-Q. Xu, H.-R. Sun, D.-M. Li, Inorganica Chim. Acta, 2000, 306, 87-93.

[60] Li, K.-M. Park, H.-J. Kim, Inorg. Chem. Commun., 2015, 60, 8-11.

[61] Z. Shi, Y. Zhou, L. Zhang, C. Mu, H. Ren, D. ul Hassan, D. Yang, H. M. Asif, RSC Adv., 2014, 4, 50277-50284.

[62] C. M. S. Santos, S. L. H. Rebelo, M. S. S. Balula, R. R. L. Martins, M. M. M. S. Pereira, M. M. Q. Simões, M. G. P. M. S. Neves, J. A. S. Cavaleiro, A. M. V. Cavaleiro, J. Mol. Catal. Chem., 2005, 231, 35-45.

[63] Costa-Coquelard, S. Sorgues, L. Ruhlmann, J. Phys. Chem. A, 2010, 114, 6394-6400.

[64] Schaming, C. Costa-Coquelard, S. Sorgues, L. Ruhlmann, I. Lampre, Appl. Catal. Gen., 2010, 373, 160-167.

[65] R. Lamare, R. Ruppert, M. Elhabiri, G. Ulrich, L. Ruhlmann, J. Weiss, C. R. Acad. Sci. Chim., 2021 https://doi.org/10.5802/crchim.105

[66] Martel, M. Gross, J. Solid State Electrochem., 2007, 11, 421-429.

[67] Y. Shen, J. Liu, J. Jiang, B. Liu, S. Dong, J. Phys. Chem. B, 2003, 107, 9744-9748

[68] Y. Shen, J. Liu, J. Jiang, B. Liu, S. Dong, Electroanalysis, 2002, 14, 1557-1563.

[69] Bazzan, W. Smith, L. C. Francesconi, C. M. Drain, Langmuir, 2008, 24, 3244-3249.

[70] J.-F. Koenig, D. Martel, Thin Solid Films, 2008, 516, 38653872.

[71] Ahmed, R. Farha, M. Goldmann, L. Ruhlmann, Chem. Commun. 2012, 49, 496-498.

[72] M. Nagai, H. Sanpeia, M. Shirakuraa, J. Mater. Chem., 2012, 22, 9222-9229.

[73] R. Long, O. M. Yaghi, Chem. Soc. Rev., 2009, 38, 12131214. 
[74] M. Zhao, S. Ou, C.-D. Wu, Acc. Chem. Res. 2014, 47, 11991207.

[75] Hagrman, P. J. Hagrman, J. Zubieta, Angew. Chem. Int. Ed. Engl., 1999, 38, 3165-3168.

[76] Z.-Y. Gu, J. Park, A. Raiff, Z. Wei, H.-C. Zhou, ChemCatChem., 2014, 6, 67-75.

[77] W. Morris, B. Volosskiy, S. Demir, F. Gándara, P. L. McGrier, H. Furukawa, D. Cascio, J. F. Stoddart, O. M. Yaghi, Inorg. Chem., 2012, 51, 6443-6445.

[78] Paille, M. Gomez-Mingot, C. Roch-Marchal, M. Haouas, Y. Benseghir, T. Pino, M.-H. Ha-Thi, G. Landrot, P. Mialane, M. Fontecave, A. Dolbecq, C. Mellot-Draznieks, ACS Appl. Mater. Interfaces, 2019, 11, 47837-47845.

[79] Paille, M. Gomez-Mingot, C. Roch-Marchal, B. LassalleKaiser, P. Mialane, M. Fontecave, C. Mellot-Draznieks, A. Dolbecq, J. Am. Chem. Soc., 2018, 140, 3613-3618.

[80] S.-L. Zhu, X. Xu, S. Ou, M. Zhao, W.-L. He, C.-D. Wu, Inorg. Chem., 2016, 55, 7295-7300.

[81] Zou, Z. Zhang, X. Xu, Q. Gong, J. Li, C.-D. Wu, J. Am. Chem. Soc., 2012, 134, 87-90.

[82] Y.-R. Wang, Q. Huang, C.-T. He, Y. Chen, J. Liu, F.-C. Shen, Y.-Q. Lan, Nat. Commun., 2018, 9, 1-8.

[83] M. Smith, G. H. Barnett, B. Evans, Z. Martynenko, J. Am. Chem. Soc., 1979, 101, 5953-5961

[84] Ruhlmann, A. Giraudeau, J. Chem. Soc. Chem. Commun., 1996, 2007-2008.

[85] Giraudeau, L. Ruhlmann, L. El Kahef, M. Gross, J. Am. Chem. Soc., 1996, 118, 2969-2979.

[86] Giraudeau, D. Schaming, J. Hao, R. Farha, M. Goldmann, L. Ruhlmann, J. Electroanal. Chem., 2010, 638, 70-75.

[87] Hao, A. Giraudeau, Z. Ping, L. Ruhlmann, Langmuir, 2008, 24, 1600-1603.

[88] Azcarate, Z. Huo, R. Farha, M. Goldmann, H. Xu, B. Hasenknopf, E. Lacôte, L. Ruhlmann, Chem. Eur. J., 2015, 21, 8271-8280.

[89] Z. Huo, S. Yang, D. Zang, R. Farha, M. Goldmann, H. Xu, B. Antoine, G. Izzet, A. Proust, L. Ruhlmann, Electrochimica Acta, 2021, 368, 137635.

[90] J. Walsh, C. T. Mallon, A. M. Bond, T. E. Keyes, R. J. Forster, Chem. Commun., 2012, 48, 3593-3595.

[91] Y. Yang, L. Xu, F. Li, X. Du, Z. Sun, J. Mater. Chem., 2010, 20, 10835-10840.

[92] Z. Sun, S. Fang, F. Li, L. Xu, Y. Hu, J. Ren, J. Photochem. Photobiol. Chem., 2013, 252, 25-30.

[93] Gao, Q. Sun, K. Wang, J. Colloid Interface Sci., 2013, 393, 92-96.

[94] Z. Huo, Y. Liang, Y. Lv, F. Melin, P. Hellwig, H. Ibrahim, M. Goldmann, C. Boudon, V. Badets, A. Bonnefont, L. Ruhlmann, Chem. Comm., 2021, 57, 1482-1485. 


\section{Entry for the Table of Contents}

Insert graphic for Table of Contents here. ((Please ensure your graphic is in one of following formats))

((max. width: $5.5 \mathrm{~cm}$; $\max$. height: $5.0 \mathrm{~cm})$ )

Please delete this box prior to submission

((max. width: $11.5 \mathrm{~cm}$; max. height: $2.5 \mathrm{~cm})$ )

Please delete this box prior to submission

Insert text for Table of Contents here. ((The Table of Contents text should give readers a short preview of the main theme of the research and results included in the paper to attract their attention into reading the paper in full. The Table of Contents text should be different from the abstract and should be no more than 450 characters including spaces.))

Institute and/or researcher Twitter usernames: ((optional))

${ }^{1}$ K. Kaygusuz, Renew. Sustain. Energy Rev., 2012, 16, 1116-1126.

2 B. Mignacca, G. Locatelli, Renew. Sustain. Energy Rev., 2020, 118, 109519.

3 "World Energy Outlook 2015 - Analysis" can be found under https://www.iea.org/reports/world-energy-outlook-2015.

${ }^{4}$ Source: European Photovoltaic Industry Association (Solar Power Europe since 2015).

http://www.epia.org/fileadmin/user_upload/Publications/GMO_2013_-_Final_PDF.pdf.

5 T. M. Bruton, Sol. Energy Mater. Sol. Cells, 2002, 72, 3-10.

6 G. Conibeer, Mater. Today, 2007, 10, 42-50.

${ }^{7}$ G. Conibeer, M. Green, R. Corkish, Y. Cho, E.-C. Cho, C.-W. Jiang, T. Fangsuwannarak, E. Pink, Y. Huang, T. Puzzer, T. Trupke, B. Richards, A. Shalav, K. Lin, Thin Solid Films, 2006, 511, 654-662.

${ }^{8}$ A. Kojima, K. Teshima, Y. Shirai, T. Miyasaka, J. Am. Chem. Soc., 2009, 131, 6050-6051.

${ }^{9}$ G. Hervé, A. Tézé, General Principles of the Synthesis of Polyoxometalates in Aqueous Solution, 2003.

10 W. G. Klemperer, in Inorg. Synth., John Wiley \& Sons, Ltd, 2007, 71-85.

11 S.-S. Wang, G.-Y. Yang, Chem. Rev., 2015, 115, 4893-4962.

12 M. Sadakane, E. Steckhan, Chem. Rev., 1998, 98, 219-238.

13 M. Zhang, Y. Zhai, S. Ru, D. Zang, S. Han, H. Yu, Y. Wei, Chem. Commun., 2018, 54, 10164-10167.

14 D. Ravelli, S. Protti, M. Fagnoni, Acc. Chem. Res., 2016, 49, 2232-2242.

15 Y. Ji, L. Huang, J. Hu, C. Streb, Y.-F. Song, Energy Environ. Sci., 2015, 8, 776-789.

16 Y.-J. Wang, W.-L. Chen, L. Chen, X.-T. Zheng, S.-S. Xu, E.-B. Wang, Inorg. Chem. Front. 2017, 4, 559-565.

${ }^{17}$ C. Busche, L. Vilà-Nadal, J. Yan, H. N. Miras, D.-L. Long, V. P. Georgiev, A. Asenov, R. H. Pedersen, N. Gadegaard, M. M. Mirza, D. J. Paul, J. M. Poblet, L. Cronin, Nature, 2014, 515, 545-549.

18 H.-K. Yang, Y.-X. Cheng, M.-M. Su, Y. Xiao, M.-B. Hu, W. Wang, Q. Wang, Bioorg. Med. Chem. Lett., 2013, 23, 1462-1466.

${ }^{19}$ H. Lv, Y. V. Geletii, C. Zhao, J. W. Vickers, G. Zhu, Z. Luo, J. Song, T. Lian, D. G. Musaev, C. L. Hill, Chem. Soc. Rev., 2012, 41, 7572-7589.

${ }^{20}$ X.-J. Kong, Z. Lin, Z.-M. Zhang, T. Zhang, W. Lin, Angew. Chem. Int. Ed Engl., 2016, 55, 6411-6416.

${ }^{21}$ H. Lv, W. Guo, K. Wu, Z. Chen, J. Bacsa, D. G. Musaev, Y. V. Geletii, S. M. Lauinger, T. Lian, C. L. Hill, J. Am. Chem. Soc., 2014, 136, 1401514018.

22 J. Ettedgui, Y. Diskin-Posner, L. Weiner, R. Neumann, J. Am. Chem. Soc., 2011, 133, 188-190.

${ }^{23}$ E. Haviv, L. J. W. Shimon, R. Neumann, Chem. Eur. J., 2017, 23, 92-95.

${ }^{24}$ W. Kühlbrandt, D. N. Wang and Y. Fujiyoshi, Nature, 1994, 367, 614. 
${ }^{25}$ G. McDermott, S. M. Prince, A. A. Freer, A. M. Hawthornthwaite-Lawless, M. Z. Papiz, R. J. Cogdell, N. W. Isaacs, Nature, 1995, $374,517$.

${ }^{26}$ R. J. Cogdell, N. W Isaacs, A. A. Freer, T. D. Howard, A. T. Gardiner, S. M. Prince, M. Z. Papiz, FEBS Lett., 2003, 555, 35.

27 M. Z. Papiz, S. M. Prince, T. Howard, R. J. Cogdell, N. W. Isaacs, J. Mol. Biol., 2003, 326, 1523.

${ }^{28}$ For an introduction to porphyrins from the point of view of synthetic chemists see: J. A. Wytko, R. Ruppert, C. Jeandon, J. Weiss Chem. Commun., 2018,54, 1550-1558.

${ }^{29}$ A. Yokoyama, T. Kojima, K. Ohkubo, S. Fukuzumi, Chem. Commun., 2007, 3997-3999.

${ }^{30}$ A. Yokoyama, T. Kojima, K. Ohkubo, S. Fukuzumi, Inorg. Chem., 2010, 49, 11190-11198.

31 a) R. Neumann, C. Abu-Gnim, J. Am. Chem. Soc., 1990, 112, 6025-6031; b) M. Sadakane, D. Tsukuma, M. H. Dickman, B. Bassil, U. Kortz, M. Hagashijima, W. Ueda, Dalton Trans., 2006, 4271- 4276.

32 A. Yokoyama, K. Ohkubo, T. Ishizuka, T. Kojima, S. Fukuzumi, Dalton Trans., 2012, 41, 10006-10013.

${ }^{33}$ A. Falber, B. P. Burton-Pye, I. Radivojevic, L. Todaro, R. Saleh, L. C. Francesconi, C. M. Drain, Eur. J. Inorg. Chem. 2009, 17, 2459-2466.

${ }^{34}$ Y. Du, A. L. Rheingold, E. A. Maatta, J. Am. Chem. Soc., 1992, 114, 345-346.

35 J. B. Strong, R. Ostrander, A. L. Rheingold, E. A. Maatta, J. Am. Chem. Soc., 1994, 116, 3601-3602.

36 J. Park, J. Y. Kim, H. So, J. Liu, Inorganica Chim. Acta, 2001, 319, 8-14.

37 D. Schaming, C. Costa-Coquelard, I. Lampre, S. Sorgues, M. Erard, X. Liu, J. Liu, L. Sun, J. Canny, R. Thouvenot, L. Ruhlmann, Inorganica Chim. Acta, 2010, 363, 2185-2192.

${ }^{38}$ C. Li, N. Mizuno, K. Yamaguchi, K. Suzuki, J. Am. Chem. Soc., 2019, 141, 7687-7692.

39 Q. Chen, D. P. Goshorn, C. P. Scholes, X. L. Tan, J. Zubieta, J. Am. Chem. Soc., 1992, 114, 4667-4681

40 W. H. Knoth, R. L. Harlow, J. Am. Chem. Soc., 1981, 103, 4265-4266.

${ }^{41}$ A. Proust, R. Thouvenot, P. Gouzerh, Chem. Commun., 2008, 1837-1852; A. Proust, B. Matt, R. Villanneau, G. Guillemot, P. Gouzerh, G. Izzet, Chem. Soc. Rev., 2012, 41, 7605-7622; P. Gouzerh, A. Proust, Chem. Rev., 1998, 98, 77-111.

42 A. Harriman, K. J. Elliott, M. A. H. Alamiry, L. L. Pleux, M. Séverac, Y. Pellegrin, E. Blart, C. Fosse, C. Cannizzo, C. R. Mayer, F. Odobel, J. Phys. Chem. C, 2009, 113, 5834-5842.

${ }^{43}$ F. Odobel, M. Séverac, Y. Pellegrin, E. Blart, C. Fosse, C. Cannizzo, C. R. Mayer, K. J. Elliott, A. Harriman, Chem. Eur. J., 2009, 15, 31303138.

44 a) V. D. Bock, H. Hiemstra, J. H. van Maarseveen, Eur. J. Org. Chem., 2006, 51-68; b) V. V. Rostovtsev, L. G. Green, V. V. Fokin, K. B. Sharpless, Angew. Chem. Int. Ed., 2002, 41, 2596-2599.

${ }^{45}$ K. J. Elliott, A. Harriman, L. Le Pleux, Y. Pellegrin, E. Blart, C. R. Mayer, F. Odobel, Phys. Chem. Chem. Phys. PCCP 2009, 11, $8767-8773$.

${ }^{46}$ H. M. Asif, Y. Zhou, L. Zhang, N. Shaheen, D. Yang, J. Li, Y. Long, A. Iqbal, Y. Li, Inorg. Chem., 2017, 56, 9436-9447.

${ }^{47}$ C. Allain, D. Schaming, N. Karakostas, M. Erard, J.-P. Gisselbrecht, S. Sorgues, I. Lampre, L. Ruhlmann, B. Hasenknopf, Dalton Trans., 2013, 42, 2745-2754.

${ }^{48}$ A. M. Brun, A. Harriman, V. Heitz, J. P. Sauvage, J. Am. Chem. Soc., 1991, 113, 8657-8663.

49 J. Rodriguez, C. Kirmaier, D. Holten, J. Am. Chem. Soc., 1989, 111, 6500-6506.

50 J. Liu, J.-W. Huang, H. Shen, H. Wang, H.-C. Yu, L.-N. Ji, Dyes Pigm., 2008, 77, 374-379.

51 I. Leray, B. Valeur, D. Paul, E. Regnier, M. Koepf, J. A. Wytko, C. Boudon, J. Weiss, Photochem Photobiol Sci., 2005, $280-286$.

52 I. Ahmed, R. Farha, Z. Huo, C. Allain, X. Wang, H. Xu, M. Goldmann, B. Hasenknopf, L. Ruhlmann, Electrochimica Acta, 2013, 110, 726734.

53 Y. Zhu, Y. Huang, Q. Li, D. Zang, J. Gu, Y. Tang, Y. Wei, Inorg. Chem., 2020, 59, 2575-2583.

${ }^{54}$ A. Iqbal, H. M. Asif, Y. Zhou, L. Zhang, T. Wang, F. Khurum Shehzad, X. Ren, Inorg. Chem., 2019, 58, 8763-8774.

${ }^{55}$ S. ul Hassan, H. M. Asif, Y. Zhou, L. Zhang, N. Qu, J. Li, Z. Shi, J. Phys. Chem. C, 2016, 120, 27587-27599.

56 M. Araghi, V. Mirkhani, M. Moghadam, S. Tangestaninejad, I. Mohammdpoor-Baltork, Dalton Trans., 2012, 41, 11745-11752.

57 M. Araghi, V. Mirkhani, M. Moghadam, S. Tangestaninejada, I. Mohammdpoor-Baltorka, Dalton Trans., 2012, 41, $3087-3094$.

58 H. M. Asifa, A. Iqbal; Y. Zhou, L. Zhang, T. Wang, M. Inam, U. Farooqi, R.Sun, Dyes Pigm., 2021, 184, 108758.

${ }^{59}$ S.-Q. Liu, J.-Q. Xu, H.-R. Sun, D.-M. Li, Inorganica Chim. Acta, 2000, 306, 87-93.

${ }^{60}$ C. Li, K.-M. Park, H.-J. Kim, Inorg. Chem. Commun., 2015, 60, 8-11.

61 Z. Shi, Y. Zhou, L. Zhang, C. Mu, H. Ren, D. ul Hassan, D. Yang, H. M. Asif, RSC Adv., 2014, 4, 50277-50284.

62 I. C. M. S. Santos, S. L. H. Rebelo, M. S. S. Balula, R. R. L. Martins, M. M. M. S. Pereira, M. M. Q. Simões, M. G. P. M. S. Neves, J. A. S. Cavaleiro, A. M. V. Cavaleiro, J. Mol. Catal. Chem., 2005, 231, 35-45.

63 C. Costa-Coquelard, S. Sorgues, L. Ruhlmann, J. Phys. Chem. A, 2010, 114, 6394-6400.

${ }^{64}$ D. Schaming, C. Costa-Coquelard, S. Sorgues, L. Ruhlmann, I. Lampre, Appl. Catal. Gen., 2010, 373, 160-167.

${ }^{65}$ R. Lamare, R. Ruppert, M. Elhabiri, G. Ulrich, L. Ruhlmann, J. Weiss, C. R. Acad. Sci. Chim., 2021, https://doi.org/10.5802/crchim.105

66 D. Martel, M. Gross, J. Solid State Electrochem., 2007, 11, 421-429.

67 Y. Shen, J. Liu, J. Jiang, B. Liu, S. Dong, J. Phys. Chem. B, 2003, 107, 9744-9748

68 Y. Shen, J. Liu, J. Jiang, B. Liu, S. Dong, Electroanalysis, 2002, 14, 1557-1563.

69 G. Bazzan, W. Smith, L. C. Francesconi, C. M. Drain, Langmuir, 2008, 24, 3244-3249.

70 J.-F. Koenig, D. Martel, Thin Solid Films, 2008, 516, 3865-3872.

71 I. Ahmed, R. Farha, M. Goldmann, L. Ruhlmann, Chem. Commun. 2012, 49, 496-498.

72 M. Nagai, H. Sanpeia, M. Shirakuraa, J. Mater. Chem., 2012, 22, 9222-9229.

73 J. R. Long, O. M. Yaghi, Chem. Soc. Rev., 2009, 38, 1213-1214.

74 M. Zhao, S. Ou, C.-D. Wu, Acc. Chem. Res. 2014, 47, 1199-1207.

75 D. Hagrman, P. J. Hagrman, J. Zubieta, Angew. Chem. Int. Ed. Engl., 1999, 38, 3165-3168.

76 Z.-Y. Gu, J. Park, A. Raiff, Z. Wei, H.-C. Zhou, ChemCatChem., 2014, 6, 67-75. 
77 W. Morris, B. Volosskiy, S. Demir, F. Gándara, P. L. McGrier, H. Furukawa, D. Cascio, J. F. Stoddart, O. M. Yaghi, Inorg. Chem., 2012, 51, 6443-6445.

78 G. Paille, M. Gomez-Mingot, C. Roch-Marchal, M. Haouas, Y. Benseghir, T. Pino, M.-H. Ha-Thi, G. Landrot, P. Mialane, M. Fontecave, A. Dolbecq, C. Mellot-Draznieks, ACS Appl. Mater. Interfaces, 2019, 11, 47837-47845.

${ }^{79}$ G. Paille, M. Gomez-Mingot, C. Roch-Marchal, B. Lassalle-Kaiser, P. Mialane, M. Fontecave, C. Mellot-Draznieks, A. Dolbecq, J. Am. Chem. Soc., 2018, 140, 3613-3618.

${ }^{80}$ S.-L. Zhu, X. Xu, S. Ou, M. Zhao, W.-L. He, C.-D. Wu, Inorg. Chem., 2016, 55, 7295-7300.

${ }^{81}$ C. Zou, Z. Zhang, X. Xu, Q. Gong, J. Li, C.-D. Wu, J. Am. Chem. Soc., 2012, 134, 87-90.

82 Y.-R. Wang, Q. Huang, C.-T. He, Y. Chen, J. Liu, F.-C. Shen, Y.-Q. Lan, Nat. Commun., 2018, 9, 1-8.

83 K. M. Smith, G. H. Barnett, B. Evans, Z. Martynenko, J. Am. Chem. Soc., 1979, 101, 5953-5961

84 L. Ruhlmann, A. Giraudeau, J. Chem. Soc. Chem. Commun., 1996, 2007-2008.

85 A. Giraudeau, L. Ruhlmann, L. El Kahef, M. Gross, J. Am. Chem. Soc., 1996, 118, 2969-2979.

${ }^{86}$ A. Giraudeau, D. Schaming, J. Hao, R. Farha, M. Goldmann, L. Ruhlmann, J. Electroanal. Chem., 2010, 638, 70-75.

87 J. Hao, A. Giraudeau, Z. Ping, L. Ruhlmann, Langmuir, 2008, 24, 1600-1603.

88 I. Azcarate, Z. Huo, R. Farha, M. Goldmann, H. Xu, B. Hasenknopf, E. Lacôte, L. Ruhlmann, Chem. Eur. J., 2015, 21, 8271-8280.

89 Z. Huo, S. Yang, D. Zang, R. Farha, M. Goldmann, H. Xu, B. Antoine, G. Izzet, A. Proust, L. Ruhlmann, Electrochimica Acta, 2021, 368, 137635.

90 J. J. Walsh, C. T. Mallon, A. M. Bond, T. E. Keyes, R. J. Forster, Chem. Commun., 2012, 48, 3593-3595.

${ }^{91}$ Y. Yang, L. Xu, F. Li, X. Du, Z. Sun, J. Mater. Chem., 2010, 20, 10835-10840.

92 Z. Sun, S. Fang, F. Li, L. Xu, Y. Hu, J. Ren, J. Photochem. Photobiol. Chem., 2013, 252, 25-30.

93 L. Gao, Q. Sun, K. Wang, J. Colloid Interface Sci., 2013, 393, 92-96.

${ }^{94}$ Z. Huo, Y. Liang, Y. Lv, F. Melin, P. Hellwig, H. Ibrahim, M. Goldmann, C. Boudon, V. Badets, A. Bonnefont, L. Ruhlmann, Chem. Comm., 2021, 57, 1482-1485. 